\title{
Erdőmüvelés aljnövényzetre gyakorolt hatásainak vizsgálata zselici bükkösben
}

\author{
SOMOGYI ZOLTÁN
}

H-6344 Érsekcsanád, Újsor 22., e-mail: somogyi.t.zoltan@gmail.com

\begin{abstract}
Somogy, Z.: Examination the silviculture's effects to herb layer in an illyrian beech forest (SW Hungary).

Abstract: The studied beech forest is situated in south-west Hungary. This paper describe the surveyed forest stand and try to introducing the influence of applied forest management method. The analysis use phytosociological characters, flora elements, life forms and social behaviour types of plant species. The composition of herb layer was changed in the steps of regeneration cutting.
\end{abstract}

Keywords: phytosociological character, social behaviour types, Vicio oroboidi-Fagetum, Zselic hills

\section{Bevezetés}

A munkám során felmért dél-dunántúli bükkös (Vicio oroboidi-Fagetum) erdőállomány Magyarország délnyugati részén, az Észak-Zselic kistájon, Kaposvártól délre, Töröcske település közelében terül el. A mindössze 240 m körüli tengerszint feletti magasságban található szubmontán bükkös állomány, hazánk legalacsonyabban található klímazonális bükkös erdei közé sorolható. Ezek a bükkösök nagy kiterjedésü, összefüggő erdőállományokat alkotnak a Bőszénfa és Kadarkút vonalában található zselici vízválasztó térségében, valamint az attól észak és dél felé kifutó lapos dombhátakon. Ezen állományok létrejöttéhez nélkülözhetetlen a jó csapadékellátottság, ami éves szinten a térségben $750 \mathrm{~mm}$ körül alakul (PÉcsı et al. szerk. 1989). A pannonkori üledékekből felépülő dombhátakat pleisztocén lösz fedi (DövÉNYı szerk. 2010). A Zselic északi részének - és az általam felmért területnek is jellemző talajtípusa a Raman-féle barna erdőtalaj. Növényföldrajzi szempontból a Zselic a dél-dunántúli flóravidék (Praeillyricum), belső-somogyi flórajárásához (Somogyicum) tartozik. A terület általános felmérése után a vágásos erdőgazdálkodás közvetlen hatásait is vizsgáltam. A Zselicben a természetes úton, önmaguktól újulni képes bükkös állományokban a véghasználat és erdőfelújítás általános módja a kétlépcsős fokoza-

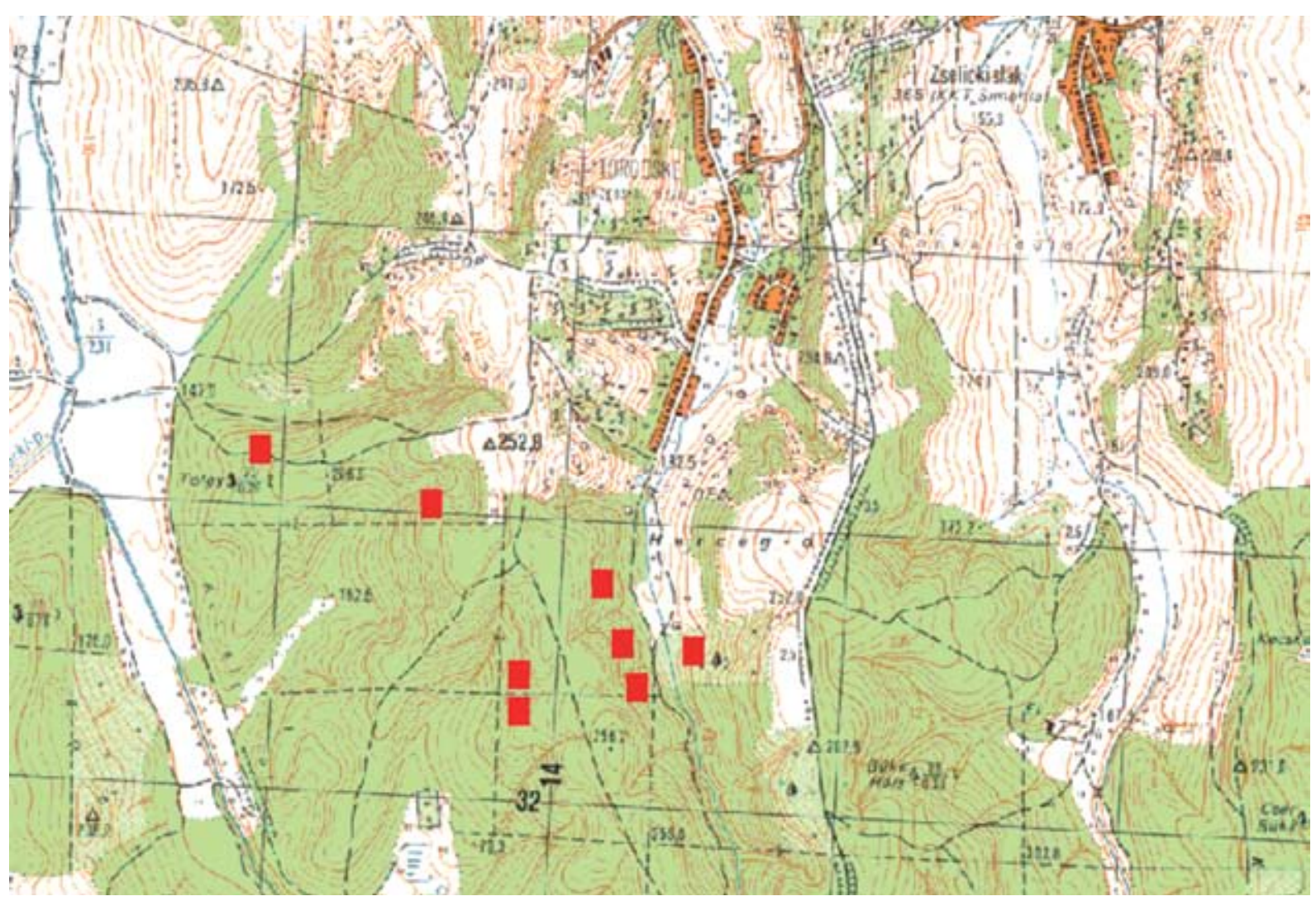

1. ábra: A mintaterületek elhelyezkedése topográfiai térképen 


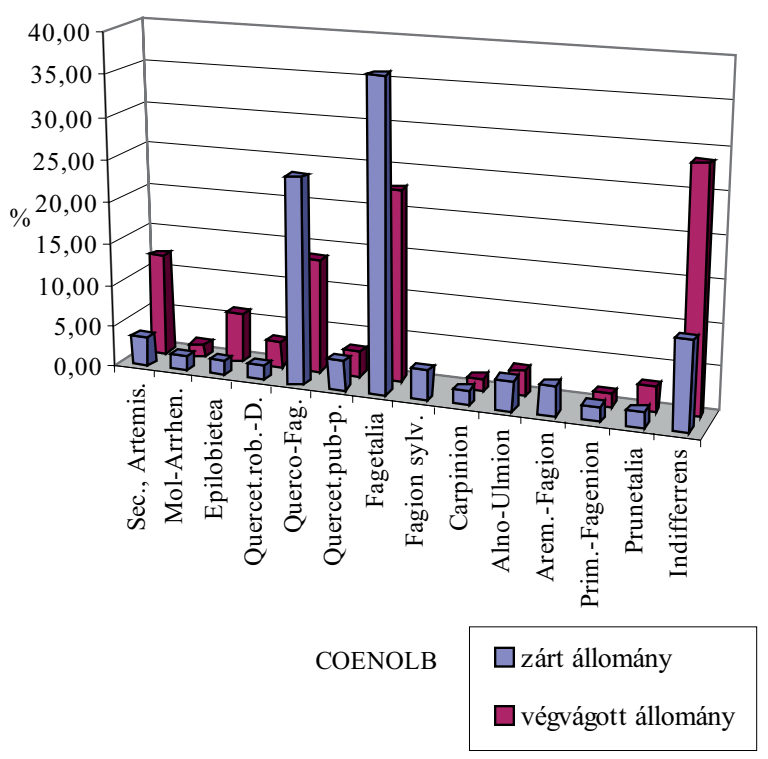

2. ábra: A fajok cönológiai karakter (COENOLB) szerinti százalékos megoszlásának változása (Id. 3. táblázat)

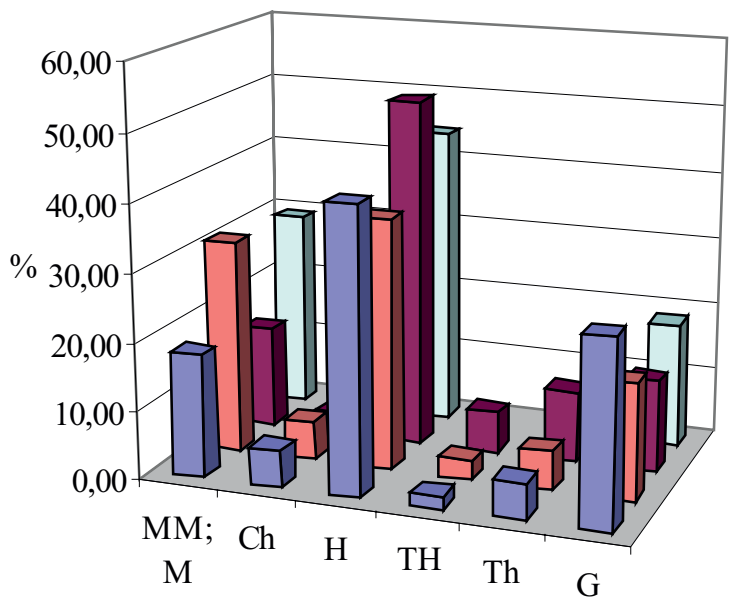

LIFE

\begin{tabular}{|l|}
\hline$\square$ zárt állomány \\
$\square$ bontott állomány \\
$\square$ végvágott állomány \\
$\square$ fiatal állomány \\
\hline
\end{tabular}

4. ábra: A fajok életforma kategóriák (LIFE) szerinti százalékos megoszlásának változása (ld. 5. táblázat)

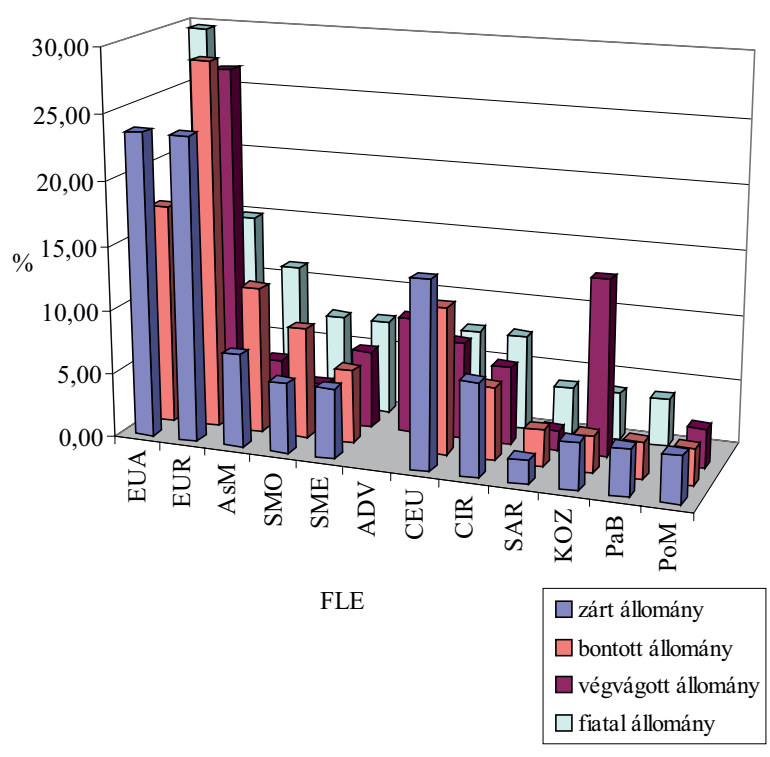

3. ábra: A fajok flóraelem-csoportok (FLE) szerinti százalékos megoszlásának változása (Id. 4. táblázat)

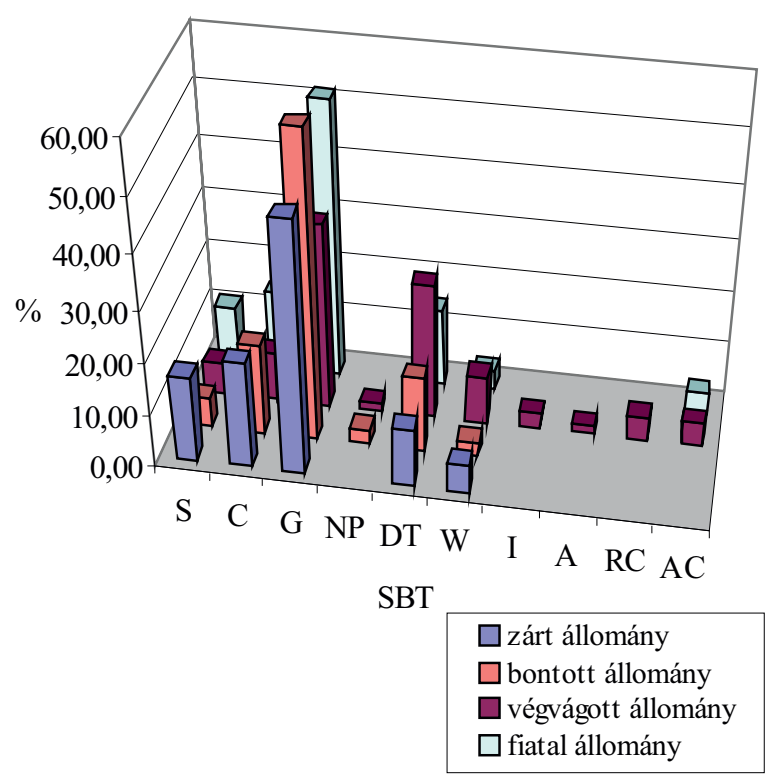

5. ábra: A fajok szociális magatartástípusok (SBT) szerinti százalékos megoszlásának változása (ld. 7. táblázat) 
tos felújítóvágás. Ez a módszer egyenletes bontáson alapul, amit a gyakorlatban rövid idő alatt folytatnak le és az egész felújítás alá vont területröl, néhány év eltéréssel termelik le az állományt. A jóformán egy-két év makkterméséből felverődő újulatból egykorú faállomány keletkezik. A természetközeli erdőgazdálkodás koncepciója megkövetelné, hogy ennél sokkal kedvezőbb vágási módok (pl. lékes felújító vágás, csoportos szálaló vágás) kerüljenek előtérbe, azonban az erdőgazdálkodási gyakorlat, egyelőre ragaszkodik a korábban kialakult módszerekhez. Ezért vizsgáltam az erdők fajösszetételében bekövetkező változásokat a felújítóvágás különböző stádiumaiban, és elemeztem a fajok által indikált hatásokat.

\section{Anyag és módszer}

A mintaterületek kijelölése és az azt megelőző részletes terepbejárás 2009-2010. márciusában történt. Ennek során nyolc kvadrát lett kijelölve (1. ábra). Ebből öt középkorú illetve idősnek mondható zárt bükkösben, egy bontott-, egy végvágott-, illetve egy pedig fiatalos (tizenöt éves) állományban. A kvadrátok mérete a társulásra feltételezhető minimiareálnak megfelelően 40×40 méterben lett meghatározva. A mintaterületek határai festéssel lettek megjelölve, sarkpontjaik pedig GPS koordinátákkal kerültek rögzítésre. Szintén 2009 és 2010 folyamán került sor a tényleges adatfelvételre. A két vegetációs időszakban négyszer ismételt felméréseket a Braun-Blanquet-féle vegetációfelvételezés módszerével végeztem (BRAUN-BLANQUET 1928, 1949). A felvétel során a borítási értékek százalékban kerültek rögzítésre. A fajok megnevezését SIMON (1992) szerint adtam meg. A cönológiai tabella kiértékeléséhez a Microsoft EXCEL programot használtam. A fokozatos felújítóvágás hatásait a fajok flóraelem, életforma, cönológiai karakter (Soó 1964-1980, HoRVÁTH et al. 1995) és szociális magatartástípus (Borhidi 1993, 1995) megoszlása alapján elemeztem. A számításokat jelenlét-hiány alapján (csoportrészesedés szerint) végeztem, illetve ahol a teljesség kedvéért szükségesnek éreztem a fajok borításával súlyozva (csoporttömeg szerint) (5., 6. táblázat) is. Ennek során összevetem az öt középkorú (1.-3. mintaterület), illetve idős korú (4., 5. mintaterület) állomány lágyszárú szintjének adatait a felújítóvágás három különböző stádiumú állományának gyepszint adataival (1. táblázat).

\section{Eredmények}

\section{A bükkös erdőtársulás jellemzése}

A felmért bükkösökben állományalkotó a Fagus sylvatica és a Tilia tomentosa (1. táblázat). Elegy fafaj a Carpinus betulus, Quercus petraea, Quercus cerris valamint megjelenik az Acer platanoides. A honos fafajok mellett megjelenik az exóta Quercus rubra. A többnyire gyér - egyedül a kevésbé záródott állományrészeken jelentősebb - cserjeszintet a Cornus mas és Ligustrum vulgare mellett a két domináns fafaj a bükk és a hárs csemetéi alkotják. A gyepszintben a Carex pilosa domináns, de idő- sebb bükkösökben nem alkot sürü állományokat. Ezekben, az idősebb erdőkben megfigyelhető a nudumhoz közeli állapot is. A lágyszárúak közül konstansan jelen van az Asarum europaeum, Dentaria bulbifera, Euphorbia amygdaloides, Galium odoratum, Viola reichenbachiana. Továbbá előfordul a védett Cephalanthera longifolia, Listera ovata, Neottia nidus-avis.

A vizsgált Dél-dunántúli bükkös erdőtársulásban a Fagetalia fajok dominálnak 36,84\%-os részesedéssel (3.táblázat). Mellettük igen jelentős a Querco-Fagetea elemek 24,56\%-os részesedése. Az illír mezofil lomberdők (Aremonio-Fagion) faja az Aremonia agrimonoides és a Ruscus hypoglossum.

A fajok flóraelem szerinti megoszlására jellemző, hogy közel ötven százalékuk $(47,27 \%)$ európai vagy eurázsiai flóraelem (4. táblázat). Továbbá jelentős részesedéssel bírnak az atlanti-szubmediterrán elterjedésű lágyszárúk, mint a Tamus communis, Ruscus aculeatus, Hedera helix, Ligustrum vulgare. Szubmediterrán flóraelem például az Isopyrum thalictroides. A társulás fontos ponto-mediterrán elterjedésü faja a Lathyrus venetus. Elmondható, hogy különböző délies elterjedésű fajok csoportrészesedése együttesen meghaladja a $20 \%$-ot.

A termöhelyen közel 42\%-os csoporttömeggel (5. táblázat), a lágyszárúak legjellemzőbb növényi életforma típusa a tőrózsa, tősarj vagy földbeli hajtással rendelkező évelő hemikriptophyta. Második legnagyobb részesedéssel az üde/árnyas erdőkre jellemző hagymás-gumós gyöktörzses növények, vagyis a geophyta fajok szerepelnek (27\%).

A szociális magatartás típusokat elemezve megállapítható, hogy a fajok a klímax társulásoknak megfelelően nagyrészt generalisták és kompetítorok (6. táblázat). Míg a lágyszárúak csaknem fele generalista, addig a természetes kompetítorok 20\%-ban vannak jelen. Ugyanakkor mivel ezek a fajok sok esetben igen nagy tömegességgel bírnak ezért borítási értékek szerint számítva- esetünkben már $42,49 \%$-os részesedét kapunk. A különböző zavarást türő és honos gyomfajok a vizsgált asszociációban csoportrészesedés szerint 16,36\%-ban vannak jelen, azonban borítássukkal súlyozva részvételük csupán 1,85\%. Végezetül a specialista fajok ismertetésével zárnám a sort melyek részesedéssel mind jelenlét-hiány, mind pedig borítással számolva 16-17\% közötti. E fajok közé sorolható az Anemona nemorosa, Aremonia agrimonoides, Galanthus nivalis, Hepatica nobilis, Isopyrum thalictroides, Lathyrus venetus, Listera ovata valamint a ritka specialista Ruscus hypoglossum.

\section{A gyepszintben történt változások a felújító vágás során}

\section{Bontott állományok}

Bontás hatására történő változás nagyban függ annak mértékétől. Az általam vizsgált állományban csak igen enyhe bontás történt, így az erdőkép lényeges változást nem mutat. Bontóvágás során a lombkorona záródása csökken, illetve megszűnik, így az erdőbel- 
sőbe több fény szürődik le, ami kedvez az újulatnak és a cserjefajoknak is.

A lombkorona felnyílása mellett fontos szempont még a bontóvágás kivitelezése alatt történt zavarás, aminek hatására zavarástürő fajok jelennek meg (5. ábra, 7. táblázat), mint a Rosa canina és az Alliaria petiolata. Valamint megjelent a termőhelyen a Persicaria hidropiper mint természetes pionír. E fajok terjedését, betelepedését árnyalhatja az a kép, hogy e vizsgált terület a végvágott terület mellett található. Azonban a vágásterületek gyakran a bontott állományok mellett helyezkednek el, elősegítve e fajok bevándorlását. A szűk ökológiai tűrőképességű specialista fajok részesedése, fajszáma csökkent, a kvadrátban egyedüli ilyen lágyszárúként a Lathyrus venetus található meg.

Kijelenthetö, hogy a fajkészlet ebben a stádiumban radikálisan nem rendeződött át, valamint a flóraelem megoszlásban sem történtek jelentős változások (3. ábra, 4. táblázat).

\section{Végvágott állományok}

Végvágás után a fajösszetételben jelentős változások történtek. A cönológiai csoportok között megfigyelhető a különböző fátlan társulások fajainak ( $p$ : Glechometalia, Arction lappae) nagyobb számú megjelenése (2. ábra, 3. táblázat) illetve növekedett a nem kötődő úgynevezett indifferens fajok száma. Csökkent a társulásra egyébként jellemző Fagetalia és QuercoFagetea fajok aránya, valamint teljesen eltűntek a Fagion sylvaticae fajai.

Megfigyelhető a flóraelem összetételben az idegenhonos (adventív) flóraelemek tömeges jelenléte (3. ábra, 4. táblázat). Megjelent idegenhonos faj a Morus alba és Sorghum halepense, melyek ugyan agresszíven nem terjednek - illetve utóbbi szántóföldeken- de jelenlétük rontja a természetességet. Észrevehető a kozmopolita elemek számának emelkedése mellett a Dél-Dunántúl bükköseire jellemző délies elterjedésű fajok részarányának csökkenése.

Csökkent a geophytonok (hagymás-gumós-gyöktörzses növények) egyedszáma, részesedése valamint megnőtt a rövid idő alatt végbement változásokhoz jobban alkalmazkodó hemitherophyta (kétévesek) és a therophyta (egyévesek) részesedése (4. ábra, 5. táblázat).

A kompetítorok részesedésének csökkenése mellett megemelkedik a zavarástürö és a honos gyomfajok aránya (5. ábra, 7. táblázat). Emellett még nagyobb problémát jelent a rudeális competítorok (Cirsium arvense, Calamagostris epigeios, Taraxacum officinale) és az agresszív tájidegen inváziós fajok (Erigeron canadensis, Phytolacca americana, Solidago canadensis, Stenactis annua) térnyerése, melyek többek között agresszív propagációs stratégiájuknak és a konkurrencia-szegény környezetnek köszönhetően kiszorítják a honos flóra fajait. A vizsgált végvágott területen az alábbi vágásterületekre jellemző gyom- és zavarástürő fajok jelenlétét mutattam ki - melyek a zárt állományokban nem fordultak elő: Arctium lappa, Atropa belladonna, Chaerophyllum temulum, Cirsium eriophorum, Clematis vitalba, Dactylis glomerata, Erodium cicutarium, Eupatorium cannabinum, Euphorbia cypariassias, Hypericum perforatum, Poa trivialis, Prunella vulgaris, Rosa canina, Sambucus ebulus, Senecio sylvaticus, Tanacetum vulgare, Torilis japonica. Életformájukra jellemző hogy egy vagy kétévesek illetve évelők. Valamint közös jellemzőjük még, hogy többnyire fénykedvelők, nem erdőtársulások fajai vagy társulásokhoz nem kötődők.

\section{Fiatal állományok}

A fiatal állományban a lombkorona erősen záródott, így a gyepszintbe rendkívül kevés fény jut le. Ez egy fajszegénynek mondható szakasz. Gyepszintjében mindössze huszonhét fajt találtam szemben a zárt idős, illetve középkorú állományok általam felírt ötvenhat fajával. (1. táblázat).

A flóraelem összetétel elemzése során kitünik, hogy adventív flóraelemek jelen vannak a vizsgált korú állományban (3. ábra, 4. táblázat)

A hagymás-gumós fajok aránya igen alacsony, csupán kétharmada a zárt idős állományban tapasztalható részesedésnek. Továbbá nincsenek jelen az egy- és kétéves életformák (4. ábra, 5. táblázat).

Jelentős az agresszív tájidegen inváziós fajok 3,7, és a zavarástürő fajok csaknem 15 százalékos részesedése (5. ábra, 7. táblázat). Továbbá a társulás karakterét meghatározó specialisták részesedése jelentősen elmarad a zárt idős korú erdőben kapott értéktől.

A vizsgált tizenöt éves korig nem észlelhetők olyan a Vicio oroboidi - Fagetum-ra jellemző fajok, mint pl: Asarum europaeum, Anemone nemorosa, Galeobdolon luteum, Isopyrum thalictroides, Ruscus aculeatus, Tamus communis.

$A z$ általam vizsgált tizenöt éves állományban úgy tapasztaltam, a regeneráció nem megy végbe ezen időtartam alatt. További kérdés hogy hosszabb időintervallumban mennyire képes az erdő gyepszintje regenerálódni. A helyreállás mértékét feltehetően nagyban befolyásolja a propagulum források távolsága. A vágásterületek nagy száma és kiterjedése miatt azonban a Zselic erdei manapság jelentős mértékben fragmentálódtak, a kevés és egymástól elszigetelt idős állományból kérdéses a visszatelepedés lehetősége.

\section{Következtetések}

A munkám során az erdőművelésnek elsősorban a gyepszintre gyakorolt hatásaival foglalkoztam egy a Zselicben található bükkös erdőállományban. A vizsgált asszociáció a dél-dunántúli bükkös (Vicio oroboidi-Fagetum) ezüsthársas és szúrós csodabogyós zselici variánsa (somogyicum) (BoRHIDI 1984), amely a Zselicben nagy összefüggö területeket borít. A fokozatos felújító vágás (bontóvágás - végvágás - fiatal állomány) hatására az erdő fajkészlete radikálisan megváltozik: 1. Megjelennek a zavarást toleráló fajok, majd a különböző tájidegen elemek. 2. A természetes vegetáció jellemző fajainak borítása csökken: ideiglenesen visszahúzódnak, illetve véglegesen eltűnnek az 
adott területröl. 3. Általánosságban fajszegény időszak a vizsgált tizenöt éves korig. 4. A zavarást türő fajok és a tájidegen elemek jelenléte a végvágott területen és a fiatal állományban is szembetűnő.

A fokozatos felújító vágás problémája természetvédelmi szempontból, hogy a bontóvágás - jobb esetben bontóvágások - után, amikor már az újulat kellő mértékben megerősödik a cserjeszintben, letermelésre kerül az állomány, így nem alakul ki változatos struktúrájú szerkezet. Ugyan a területen nem végeznek semmiféle talaj előkészítést, hiszen az erdő magától újul fel, azonban az eredményeim azt mutatják, hogy a bontóvágás és különösen az állomány teljes letermelése után a gyepszint fajszerkezete átalakul. Sajnos több, a társulásra jellemző értékes és védett faj tűnik el. E hatalmas stressz, továbbá a gyors változások, valamint a megváltozott termőhelyi körülmények hatására kérdéses a visszarendeződés mértéke. Ez végső soron a biológiai sokféleség csökkenéséhez vezet, ami hátrányosan érinti az erdei életközösség egészét.

\section{Köszönetnyilvánítás}

Ezúton szeretném megköszönni Dr. Juhász Magdolna botanikusnak a támogatását, útmutatását. Továbbá Pintér András természetvédelmi őrkerület-vezetőnek a mintaterületek kijelölésében nyújtott segítségét.

\section{Irodalom}

BoRHIDI A. 1960: Fagion-Gesellchafften und Waldtypen des Hügellandes von Zselic - Annales Universitatis Budapestensis, Sectio Biologica 3: 75-87.

BorHIDI A. 1963a: Die Zönologie des Verbandes Fagion illyricum I. Allgemeiner teil - Acta Botanica Hungarica 9: 259-297.

BoRHIDI A. 1963b: A Zselic erdei és kapcsolatuk a nyugat-balkáni bükkösökkel. - Kandidátusi értekezés (kézirat).

BorHIDI A. 1965: Die Zönologie des Verbandes Fagion illyricum II. Systematicher Teil. - Acta Botanica Hungarica 11: 53-102.

BoRHIDI A. 1966: Die Zönologie des Verbandes Fagion illyricum III. Die Phytogeographischen Verhaltnisse. - Annales Universitatis Budapestensis, Sectio Biologica 8: 33-45.

BoRHIDI A. 1968: Die geobotanischen Verhaltnisse der EichenHainbuchenwalder Südosteuropas. - Feddes Repert 78: 109130.

BorHIDI A. 1984: A Zselic erdei. - Dunántúli Dolgozatok (A) Természettudományi Sorozat 4: 1-145.

BoRHIDI A. 1993: A magyar flóra szociális magatartás típusai, természetességi és relatív ökológiai értékszámai. - KTM Természetvédelmi Hivatala és a Janus Pannonius Tudományegyetem kiadványa, Pécs, 95 pp.

BoRHIDI A. 1995: Social behaviour types, their naturalness and relative ecological indicator values of the higher plants of the Hungarian Flora. - Acta Botanica Hungarica 39: 97-182.
Braun-Blanquet, J. 1928: Pflanzensoziologie. - Julius Springer Verlag, Berlin, $330 \mathrm{pp}$.

Braun-Blanquet, J. 1949: Übersicht der Pflanzengesellschaften Ratiens III-IV. - Vegetatio 1: 285-316., 2: 20-37.

DöVÉNYı Z. (szerk) 2010: Magyarország kistájainak katasztere. - MTA Földrajztudományi Kutatóintézet, Budapest pp. 522-523.

HoRVÁt A. 1958: A mecseki bükkösök (Fagetum silvaticae mecsekense) erdőtípusai. - Janus Pannonius Múzeum Évkönyve 31-48. (1959)

HoRvÁt A. 1972: Die Vegetation des Mecsekgebirges und seiner Umgebung. - Akadémiai Kiadó, Budapest, 376 pp.

Horváth F., Dobolyı Z., Morschhauser T., LöKös L., Karas L., SzerdaHELYI T. (1995): FLÓRA adatbázis 1.2 Taxon-lista és attribútum állomány - MTA Ökológiai és Botanikai Kutatóintézete és MTM Növénytár, Vácrátót - Budapest 252 pp.

KEVEY B. 2008: Magyarország erdőtársulásai. - Tilia 14: 273-275.

Pécsı M. et al. szerk. 1989: Magyarország Nemzeti Atlasza. - Kartográfiai Vállalat, Budapest, pp.53-56.

SimON T. 1992: A magyarországi edényes flóra határozója. Harasztokvirágos növények. - Nemzeti Tankönyvkiadó, Budapest.

Soó R. 1964-1980: A magyar flóra és vegetáció rendszertani-növényföldrajzi kézikönyve I-VI. - Akadémiai Kiadó, Budapest. 


\section{1. táblázat: Cönológiai felvételek tabellája}

\begin{tabular}{|c|c|c|c|c|c|c|c|c|c|c|c|c|c|}
\hline Mintaterület száma & 1. & 2. & 3. & 4. & 5. & $\mathbf{K}$ & 6. & 7. & 8. & LIFE & FLE & COENOLB & SMT \\
\hline \multicolumn{14}{|l|}{ Lombkoronaszint } \\
\hline Acer platanoides & - & 1 & - & - & - & I & - & - & - & $\mathrm{MM}$ & $\mathrm{CEU}$ & 8.4 .3 & $\mathrm{G}$ \\
\hline Carpinus betullus & - & 5 & 15 & - & 3 & III & 3 & - & - & MM-M & $\mathrm{PaB}$ & 8.4 & $\mathrm{C}$ \\
\hline Fagus sylvatica & 14 & 14 & 17 & 75 & 87 & $\mathrm{~V}$ & 65 & - & 40 & MM-M & CEU & 8.4 .3 .1 & $\mathrm{C}$ \\
\hline Quercus cerris & - & - & 10 & 10 & - & II & 9 & - & - & MM-M & SMO & 8.4 .2 & $\mathrm{C}$ \\
\hline Quercus patreae & - & - & 5 & - & 10 & II & 4 & - & - & MM-M & $\mathrm{CEU}$ & 8.4 & $\mathrm{C}$ \\
\hline Quercus rubra & - & - & 5 & - & - & I & - & - & - & MM-M & $\mathrm{ADV}$ & I & $\mathrm{I}$ \\
\hline Tilia tomentosa & 86 & 80 & 48 & 15 & - & IV & 19 & - & 60 & $\mathrm{MM}$ & $\mathrm{PaB}$ & 8.4 & $\mathrm{C}$ \\
\hline \multicolumn{14}{|l|}{ Cserjeszint } \\
\hline Acer campestre & 0,01 & 0,1 & 1 & - & 0,1 & IV & 1 & 0,1 & 1,5 & $\mathrm{MM}$ & EUR & 8.4 & G \\
\hline Acer platanoides & 0,01 & 0,01 & - & - & 0,1 & III & 1 & 0,1 & 0,5 & $\mathrm{MM}$ & $\mathrm{CEU}$ & 8.4 .3 & $\mathrm{G}$ \\
\hline Ailanthus altissima & - & - & - & - & - & & - & 0,1 & - & MM & $\mathrm{ADV}$ & Indiff. & $\mathrm{AC}$ \\
\hline Atropa belladonna & - & - & - & - & - & & - & 5 & - & $\mathrm{H}$ & AsM & 6.2 .1 .2 & DT \\
\hline Carpinus betullus & - & 0,1 & - & - & 0,1 & II & - & - & - & MM-M & $\mathrm{PaB}$ & 8.4 & $\mathrm{C}$ \\
\hline Cerasus avium & - & - & - & - & - & & - & 0,1 & - & M-MM & SME & 8.4 .3 .2 & $\mathrm{~S}$ \\
\hline Clematis vitalba & - & - & - & - & - & & - & 2 & 2 & N-E & SME & 8.4 & DT \\
\hline Cornus mas & - & - & - & 0,01 & - & I & 3 & - & 0,5 & $\mathrm{M}$ & SME & 8.4 .2 & G \\
\hline Fagus sylvatica & 0,01 & 0,1 & 1 & 35 & 40 & $\mathrm{~V}$ & 30 & 65 & 7 & MM-M & $\mathrm{CEU}$ & 8.4 .3 .1 & $\mathrm{C}$ \\
\hline Ligustrum vulgare & 0,1 & 0,1 & 0,1 & - & - & III & 8 & - & 1 & M & AsM & 8.4 & G \\
\hline Padus avium & - & - & - & - & - & & - & 0,1 & - & $\mathrm{MM}$ & EUA & 8.4 .3 .3 & $\mathrm{~S}$ \\
\hline Physalis alkekengi & - & - & - & - & - & & - & 0,1 & - & $\mathrm{H}$ & SME & 8.4 .3 .3 & G \\
\hline Phytolaca americana & - & - & - & - & - & & - & 5 & - & $\mathrm{H}$ & $\mathrm{ADV}$ & 3.5 .2 & A \\
\hline Quercus cerris & - & - & - & 0,1 & - & I & 0,1 & - & 1 & MM-M & SMO & 8.4 .2 & $\mathrm{C}$ \\
\hline Rosa cannina & - & - & - & - & - & & - & 4 & - & $\mathrm{M}$ & EUR & 8.6 .1 & DT \\
\hline Rubus caesius & - & - & - & - & - & & - & 15 & 8 & $\mathrm{H}-\mathrm{N}$ & EUA & Indiff. & DT \\
\hline Salix cinerea & - & - & - & - & - & & - & 1 & - & $\mathrm{M}$ & EUA & 8.5 .2 .1 & $\mathrm{C}$ \\
\hline Staphylea pinnata & 0,01 & 0,1 & - & 0,1 & - & III & 4 & 4 & 3 & $\mathrm{M}$ & SMO & 8.4 .3 .2 & $\mathrm{~S}$ \\
\hline Tilia tomentosa & 0,1 & 1 & 3 & 20 & 5 & $\mathrm{~V}$ & 40 & 65 & 23 & $\mathrm{MM}$ & $\mathrm{PaB}$ & 8.4 & $\mathrm{C}$ \\
\hline Ulmus glabra & 0,1 & - & - & - & - & I & 1 & - & 0,5 & MM-M & EUR & 8.4 .3 & G \\
\hline \multicolumn{14}{|l|}{ Gyepszint: } \\
\hline Acer campestre & 0,01 & 0,1 & 1 & - & 0,1 & IV & 0,1 & 0,1 & 2 & $\mathrm{MM}$ & EUR & 8.4 & G \\
\hline Acer platanoides & 0,01 & 0,01 & 0,1 & - & - & III & 0,1 & 0,1 & 0,1 & MM & $\mathrm{CEU}$ & 8.4 .3 & $\mathrm{G}$ \\
\hline Actaea spicata & - & - & - & 0,01 & - & I & 0,01 & - & - & $\mathrm{H}$ & EUA & 8.4 .3 & G \\
\hline Ajuga reptans & 0,5 & 1,5 & 1 & - & - & III & 0,1 & 5 & 1 & $\mathrm{H}-\mathrm{Ch}$ & EUR & Indiff. & DT \\
\hline Allaria petiolata & - & - & - & 0,1 & - & I & 3 & 3 & - & TH-H & EUA & Indiff. & DT \\
\hline Anemone nemorosa & 1 & 10 & 40 & - & - & III & - & - & - & $\mathrm{G}$ & EUR & 8.4 .3 & $\mathrm{~S}$ \\
\hline Anthriscus cerefolium & - & - & 0,01 & - & - & $\mathrm{I}$ & - & - & - & $\mathrm{Th}$ & PoM & 3.5 .2 .2 & $\mathrm{~W}$ \\
\hline Arctium lappa & - & - & - & - & - & & - & 0,1 & - & $\mathrm{TH}$ & EUA & 3.5 .1 .1 & $\mathrm{~W}$ \\
\hline Aremonia agrimonoides & - & - & 0,1 & - & - & I & - & - & - & $\mathrm{H}$ & SMO & 8.4 .3 .4 & $\mathrm{~S}$ \\
\hline Arum maculatum & - & 0,1 & - & - & - & I & - & - & - & G & CEU & 8.4 .3 & G \\
\hline Asarum europaeum & 2 & 1 & 20 & 0,1 & 0,1 & $\mathrm{~V}$ & - & - & - & $\mathrm{H}-\mathrm{G}$ & EUA & 8.4 .3 & G \\
\hline Athyrium filix-femina & - & - & - & - & - & & - & 0,01 & - & $\mathrm{H}$ & $\mathrm{KOZ}$ & Indiff. & $\mathrm{G}$ \\
\hline Atropa belladonna & - & - & - & - & - & & - & 3 & - & $\mathrm{H}$ & AsM & 6.2 .1 .2 & DT \\
\hline Brachypodium sylvaticum & - & 1 & 1 & - & - & II & - & & - & $\mathrm{H}$ & EUA & Indiff. & G \\
\hline Bromus benekenii & - & - & - & - & - & & - & 0,1 & - & $\mathrm{H}$ & EUA & 8.4 .3 & G \\
\hline Calamagostris epigeios & - & - & - & - & - & & - & 0,1 & - & $\mathrm{H}$ & EUA & Indiff. & $\mathrm{RC}$ \\
\hline Campanula patula & - & - & - & - & - & & - & 0,1 & - & $\mathrm{TH}$ & EUR & 5.4 & G \\
\hline Carex digitata & 3 & 3 & 3 & 2 & 1 & $\mathrm{~V}$ & - & - & 3 & $\mathrm{H}$ & EUR & 8.4 .3 & G \\
\hline Carex michelii & - & - & - & - & - & & 3 & - & - & $\mathrm{H}$ & SMO & 8.4 .2 & G \\
\hline Carex pilosa & 40 & 30 & 60 & 30 & 25 & $\mathrm{~V}$ & 10 & 16 & 3 & $\mathrm{H}$ & SAR & 8.4 .3 & $\mathrm{C}$ \\
\hline
\end{tabular}




\section{1. táblázat: Cönológiai felvételek tabellája}

\begin{tabular}{|c|c|c|c|c|c|c|c|c|c|c|c|c|c|}
\hline Mintaterület száma & 1. & 2. & 3. & 4. & 5. & $\mathbf{K}$ & 6. & 7. & 8. & LIFE & FLE & COENOLB & SMT \\
\hline \multicolumn{14}{|l|}{ Gyepszint: } \\
\hline Carex sylvatica & 3 & 3 & 3 & 2 & 1 & $\mathrm{~V}$ & - & - & - & $\mathrm{H}$ & EUR & 5.4 .3 & G \\
\hline Carpinus betullus & - & 0,1 & - & - & 0,1 & II & - & - & - & MM-M & $\mathrm{PaB}$ & 8.4 & $\mathrm{C}$ \\
\hline Cephalanthera longifolia & - & - & - & - & 0,01 & I & - & - & 0,01 & G & EUR & 8.4 & $\mathrm{G}$ \\
\hline Chaerophyllum temulum & - & - & - & - & - & & - & 0,1 & - & Th-TH & EUR & 3.5 .3 & DT \\
\hline Circea lutetiana & - & 0,1 & 1 & - & - & II & 2 & 1 & - & $\mathrm{G}$ & CIR & 8.4 .3 & $\mathrm{G}$ \\
\hline Cirsium arvense & - & - & - & - & - & & - & 1 & - & G & EUA & Indiff. & $\mathrm{RC}$ \\
\hline Cirsium eriophorum & - & - & - & - & - & & - & 1 & - & $\mathrm{TH}$ & $\mathrm{CEU}$ & 3.5 .4 & $\mathrm{~W}$ \\
\hline Clematis vitalba & - & - & - & - & - & & - & 1 & - & N-E & SME & 8.4 & DT \\
\hline Clinopodium vulgare & - & - & - & - & - & & - & 0,5 & - & $\mathrm{H}$ & CIR & 8.4 & $\mathrm{G}$ \\
\hline Coridalis cava & 0,1 & - & 0,1 & 0,01 & - & III & - & 0,1 & - & $\mathrm{G}$ & $\mathrm{CEU}$ & 8.4 .3 & $\mathrm{C}$ \\
\hline Cornus mas & - & - & - & - & - & & 4 & - & - & M & SME & 8.4 .2 & $\mathrm{G}$ \\
\hline Dactylis glomerata & - & - & - & - & - & & & 0,1 & - & $\mathrm{H}$ & $\mathrm{KOZ}$ & Indiff. & DT \\
\hline Dentaria bulbifera & 30 & 20 & 40 & 1 & 0,01 & $\mathrm{~V}$ & 20 & 20 & 25 & G & EUR & 8.4 .3 & $\mathrm{G}$ \\
\hline Dryopteris filix-mas & 0,01 & 0,1 & - & 0,01 & - & III & - & 0,1 & 0,1 & $\mathrm{H}$ & $\mathrm{KOZ}$ & 8.4 & $\mathrm{G}$ \\
\hline Epipactis leptochila & - & - & - & - & - & & 0,05 & - & - & G & EUR & 8.4 & $\mathrm{G}$ \\
\hline Epipactis purpurata & - & - & - & - & - & & - & - & 0,01 & G & $\mathrm{CEU}$ & 8.4 .3 & $\mathrm{~S}$ \\
\hline Erigeron canadensis & - & - & - & - & - & & - & 10 & - & Th-TH & $\mathrm{ADV}$ & Indiff. & $\mathrm{AC}$ \\
\hline Erodium cicutarium & - & - & - & - & - & & - & 0,1 & - & $\mathrm{Th}$ & $\mathrm{KOZ}$ & Indiff. & $\mathrm{W}$ \\
\hline Eupatorium cannabinum & - & - & - & - & - & & - & 1 & - & $\mathrm{H}$ & EUA & Indiff. & DT \\
\hline Euphorbia amygdaloides & 0,1 & 0,1 & 0,1 & 0,1 & 0,01 & $\mathrm{~V}$ & 1 & 10 & 1 & $\mathrm{Ch}$ & SME & 8.4 .3 & $\mathrm{G}$ \\
\hline Euphorbia cypariassias & - & - & - & - & - & - & - & 0,1 & - & $\mathrm{H}(\mathrm{G})$ & EUA & Indiff. & DT \\
\hline Fagus sylvatica & 0,01 & 0,1 & 1 & 25 & 25 & $\mathrm{~V}$ & 25 & - & - & MM-M & CEU & 8.4 .3 .1 & $\mathrm{C}$ \\
\hline Fragaria vesca & - & - & 0,01 & - & - & I & - & 3 & 1 & $\mathrm{H}$ & CIR & 8.4 & $\mathrm{G}$ \\
\hline Galanthus nivalis & - & - & 50 & - & - & I & - & - & - & G & $\mathrm{CEU}$ & 8.4 .3 & $\mathrm{~S}$ \\
\hline Galeobdolom luteum & 0,01 & 0,1 & 0,01 & - & - & III & - & - & - & $\mathrm{H}(\mathrm{Ch})$ & CEU & 8.4 .3 & G \\
\hline Galium aparine & - & 0,1 & 1 & 0,1 & - & III & 0,1 & 1 & - & $\mathrm{Th}$ & $\mathrm{KOZ}$ & Indiff. & $\mathrm{W}$ \\
\hline Galium odoratum & 10 & 1 & 1 & 1 & 0,1 & $\mathrm{~V}$ & 15 & 15 & 4 & $\mathrm{G}$ & EUA & 8.4 .3 & $\mathrm{C}$ \\
\hline Geum urbanum & 0,01 & 0,01 & 0,01 & - & - & III & - & 4 & 0,1 & $\mathrm{H}$ & CIR & 6.2 & DT \\
\hline Glechoma hederacea & - & 0,1 & 1 & - & - & II & 1 & - & 0,1 & $\mathrm{H}(\mathrm{Ch}-\mathrm{G})$ & EUA & Indiff. & DT \\
\hline Hedera helix & 10 & 40 & 5 & 1 & - & IV & 15 & 10 & 35 & M-E & AsM & 8.4 & $\mathrm{G}$ \\
\hline Hepatica nobilis & - & 5 & - & - & - & I & - & 0,01 & - & G & EUR & 8.4 .3 & $\mathrm{~S}$ \\
\hline Hypericum perforatum & - & - & - & - & - & - & - & 1 & - & $\mathrm{H}$ & EUA & Indiff. & DT \\
\hline Isopyrum thalictroides & 1 & 0,1 & - & - & - & II & - & - & - & G & SME & 8.4 .3 .1 & $\mathrm{~S}$ \\
\hline Lamium maculatum & - & - & 0,1 & - & - & I & - & - & - & $\mathrm{H}(\mathrm{Ch})$ & EUR & Indiff. & DT \\
\hline Lathyrus venetus & 0,5 & 1 & 0,5 & - & - & III & 1 & 1 & - & $\mathrm{H}$ & PoM & 8.4 .3 .4 .1 & $\mathrm{~S}$ \\
\hline Ligustrum vulgare & 0,1 & 0,1 & 3 & - & - & III & 8 & 1 & 1 & M & AsM & 8.4 & $\mathrm{G}$ \\
\hline Listera ovata & - & 0,1 & - & - & - & I & - & - & 0,01 & $\mathrm{G}$ & EUA & 8.4 .3 .3 & $\mathrm{~S}$ \\
\hline Lysimachia punctata & - & - & - & - & - & - & - & 1 & - & $\mathrm{H}$ & PoM & 8.3 & $\mathrm{G}$ \\
\hline Meliitis carptica & - & 0,01 & - & - & - & I & 0,1 & - & - & $\mathrm{H}$ & CEU & 8.4 .2 & G \\
\hline Mercurialis perennis & - & 0,1 & 1 & 0,1 & 0,01 & IV & 5 & 0,1 & - & $\mathrm{H}$ & EUR & 8.4 .3 & $\mathrm{C}$ \\
\hline Monotropa hypopitys & - & - & - & - & 0,1 & I & - & - & - & $\mathrm{G}$ & CIR & 8.3 & $\mathrm{G}$ \\
\hline Morus alba & - & - & - & - & - & & - & 0,1 & - & $\mathrm{MM}$ & $\mathrm{ADV}$ & 6.2 .3 & I \\
\hline Mycelis muralis & - & 0,01 & - & - & - & I & 0,1 & 4 & - & $\mathrm{H}$ & EUR & 8.4 & $\mathrm{G}$ \\
\hline Neottia nitidus-avis & 0,01 & - & 0,01 & - & 0,01 & III & - & - & - & $\mathrm{G}$ & EUA & 8.4 .3 & $\mathrm{G}$ \\
\hline Padus avium & - & - & - & - & - & & - & 0,1 & - & $\mathrm{MM}$ & EUA & 8.4 .3 .3 & $\mathrm{~S}$ \\
\hline Persicaria hidropiper & - & - & - & - & - & & 0,01 & - & - & Th & CIR & 3.2 .1 & NP \\
\hline Physalis alkekengi & - & - & - & - & - & & - & 0,1 & - & $\mathrm{H}$ & SME & 8.4 .3 .3 & $\mathrm{G}$ \\
\hline Phytolaca americana & - & - & - & - & - & & - & 3 & - & $\mathrm{H}$ & $\mathrm{ADV}$ & 3.5 .2 & A \\
\hline Platanthera bifolia & - & - & - & - & - & & 0,01 & - & - & G & EUA & 8.4 & $\mathrm{G}$ \\
\hline
\end{tabular}




\section{1. táblázat: Cönológiai felvételek tabellája}

\begin{tabular}{|c|c|c|c|c|c|c|c|c|c|c|c|c|c|}
\hline Mintaterület száma & 1. & 2. & 3. & 4. & 5. & $\mathbf{K}$ & 6. & 7. & 8. & LIFE & FLE & COENOLB & SMT \\
\hline \multicolumn{14}{|l|}{ Gyepszint: } \\
\hline Poa trivialis & - & - & - & - & - & & - & 0,01 & - & $\mathrm{H}$ & $\mathrm{KOZ}$ & Indiff. & DT \\
\hline Polygonatum multiflorum & 0,1 & 1 & 1 & - & - & III & 0,1 & 0,1 & - & G & EUA & 8.4 .3 & G \\
\hline Prunella vulgaris & - & - & - & - & - & & - & 0,1 & - & $\mathrm{H}$ & $\mathrm{KOZ}$ & Indiff. & DT \\
\hline Pulmonaria officinalis & 0,1 & 0,1 & 0,1 & 0,01 & - & IV & 1 & 3 & - & $\mathrm{H}$ & CEU & 8.4 .3 & $\mathrm{G}$ \\
\hline Quercus cerris & - & - & 0,1 & 1 & - & II & 0,1 & 0,1 & 0,1 & MM-M & SMO & 8.4 .2 & $\mathrm{C}$ \\
\hline Quercus patreae & - & - & 0,1 & - & 0,1 & II & - & - & - & MM-M & CEU & 8.4 & $\mathrm{C}$ \\
\hline Rannunculus ficaria & 5 & 1 & 1 & - & 0,01 & IV & - & 0,1 & - & H-G & EUA & 8.4 .3 & $\mathrm{C}$ \\
\hline Rosa canina & - & - & - & - & - & & 0,1 & 4 & - & M & EUR & 8.6 .1 & DT \\
\hline Rubus hirtus & 2 & 2 & 2 & - & - & III & 15 & 15 & 15 & $\mathrm{H}-\mathrm{N}$ & CEU & 8.6 .1 .2 & DT \\
\hline Rumex acetosella & - & - & - & - & - & & - & 1 & - & $\mathrm{H}(\mathrm{G})$ & $\mathrm{KOZ}$ & Indiff. & NP \\
\hline Rumex sanguineus & - & - & 0,01 & - & - & I & - & - & - & $\mathrm{H}$ & EUR & 8.4 .3 & G \\
\hline Ruscus aculeatus & 35 & 5 & 5 & - & - & III & 5 & - & 4 & $\mathrm{Ch}$ & AsM & 8.4 & G \\
\hline Ruscus hypoglossum & - & - & 1 & - & - & I & - & - & - & $\mathrm{Ch}$ & SME & 8.4 .3 .4 & $\mathrm{Sr}$ \\
\hline Salvia glutinosa & - & - & - & - & - & & 1 & 6 & 0,01 & $\mathrm{H}$ & EUR & 8.4 .3 & G \\
\hline Sambucus ebulus & - & - & - & - & - & & - & 2 & 0,1 & $\mathrm{H}$ & SME & 3.5.1.1 & $\mathrm{W}$ \\
\hline Senecio sylvaticus & - & - & - & - & - & & - & 1 & - & Th & EUR & 6.2 .1 .1 & DT \\
\hline Solidago canadensis & - & - & - & - & - & & - & 8 & 2 & $\mathrm{H}$ & $\mathrm{ADV}$ & 3.5 .3 & $\mathrm{AC}$ \\
\hline Sorghum halepense & - & - & - & - & - & & - & 1 & - & $\mathrm{G}(\mathrm{H})$ & $\mathrm{ADV}$ & 3.4 & I \\
\hline Stachys sylvatica & - & - & - & - & - & & - & 0,1 & - & $\mathrm{H}$ & EUA & 8.4 .3 & G \\
\hline Staphylea pinnata & - & - & 0,1 & 0,1 & - & II & 5 & 3 & 3 & M & SMO & 8.4 .3 .2 & S \\
\hline Stellaria holostella & - & - & 0,01 & - & - & I & - & - & - & $\mathrm{H}$ & EUA & 8.4 & $\mathrm{C}$ \\
\hline Stenactis aпnиа & - & - & - & - & - & & - & 8 & - & Th & $\mathrm{ADV}$ & Indiff. & $\mathrm{AC}$ \\
\hline Symphytum tuberosum & - & - & - & - & - & & - & 1 & - & G & CEU & 8.4 .2 & G \\
\hline Tamus communis & 0,1 & 0,1 & 0,1 & 0,01 & - & IV & 0,1 & - & - & G & AsM & 8.4 & G \\
\hline Tanacetum vulgare & - & - & - & - & - & & - & 1 & - & $\mathrm{H}$ & EUA & 3.5 .2 .1 & $\mathrm{~W}$ \\
\hline Taraxacum officinale & - & - & - & - & - & & - & 1 & - & $\mathrm{H}$ & EUA & Indiff. & $\mathrm{RC}$ \\
\hline Tilia tomentosa & 0,1 & - & 3 & 14 & 1 & IV & 25 & - & 1 & MM & $\mathrm{PaB}$ & 8.4 & $\mathrm{C}$ \\
\hline Torilis japonica & - & - & - & - & - & & - & 0,1 & - & Th-TH & EUA & Indiff. & DT \\
\hline Ulmus glabra & - & - & - & - & - & & 0,1 & - & 0,5 & MM-M & EUR & 8.4 .3 & G \\
\hline Urtica dioica & - & - & - & - & - & & - & 1 & - & $\mathrm{H}$ & $\mathrm{KOZ}$ & Indiff. & DT \\
\hline Veronica hederifolia & - & 0,5 & - & - & - & I & - & - & - & Th & EUA & 3.4 & $\mathrm{~W}$ \\
\hline Veronica officinalis & - & - & - & - & - & & - & 0,1 & - & $\mathrm{Ch}$ & EUA & 8.3 .1 & G \\
\hline Viola reichenbachiana & 1 & 1 & 0,1 & 0,1 & 0,01 & $\mathrm{~V}$ & 2 & 5 & 0,1 & $\mathrm{H}$ & EUR & 8.4 & G \\
\hline
\end{tabular}


ZSELICI BÜKKÖSBEN

\section{2. táblázat: Felvételi adatok}

\begin{tabular}{|c|c|c|c|c|c|c|c|c|}
\hline Sorszám & 1 & 2 & 3 & 4 & 5 & 6 & 7 & 8 \\
\hline Felvétel helye & Töröcske & Töröcske & Töröcske & Töröcske & Töröcske & Töröcske & Töröcske & Töröcske \\
\hline Felvételi évszám & 2009 & 2009 & 2009 & 2009 & 2009 & 2010 & 2010 & 2010 \\
\hline Kitettség & $\mathrm{E}$ & $\mathrm{E}$ & W & $\mathrm{N}$ & $\mathrm{N}$ & W & W & $\mathrm{NE}$ \\
\hline Lejtőszög (fok) & 15 & 10 & 10 & 20 & 10 & 15 & 20 & 18 \\
\hline Felvételi ter. nagysága (m2) & 1600 & 1600 & 1600 & 1600 & 1600 & 1600 & 1600 & 1600 \\
\hline Lombkoronaszint borítása (\%) & 90 & 90 & 85 & 85 & 80 & 75 & - & 95 \\
\hline Cserjeszint borítása (\%) & 0,1 & 1 & 1 & 30 & 20 & 40 & 100 & 35 \\
\hline Gyepszint borítása (\%) & 60 & 70 & 80 & 35 & 35 & 70 & 80 & 35 \\
\hline Cserjeszint magassága $(\mathrm{cm})$ & 65 & 80 & 50 & 100 & 90 & 150 & 250 & 80 \\
\hline Gyepszint magassága (cm) & 20 & 20 & 25 & 15 & 15 & 20 & 30 & 15 \\
\hline Átlagos törzsátmérö $(\mathrm{cm})$ & $15-30$ & $15-30$ & $10-30$ & $30-45$ & $35-55$ & $30-45$ & - & $5-8$ \\
\hline
\end{tabular}

\section{3. táblázat: A fajok cönológiai karakter (COENOLB) szerinti százalékos megoszlásának változása (Id. 2. ábra)}

\begin{tabular}{|lcc|}
\hline \multicolumn{1}{|c}{ cönológiai karakter } & zárt állomány (\%) & végvágott állomány (\%) \\
Secelietea., Artemisietea. & 3,51 & 12,12 \\
Molinio-Arrhenatheretea & 1,75 & 1,52 \\
Epilobietea angustifolii & 1,75 & 6,06 \\
Quercetea robori-petraeae & 1,75 & 3,03 \\
Querco-Fagetea & 24,56 & 13,64 \\
Quercet.pubescentis-petraeae & 3,51 & 3,03 \\
Fagetalia & 36,84 & 22,73 \\
Fagion sylvaticae & 3,51 & - \\
Carpinion betuli & 1,75 & 1,52 \\
Alno-Ulmion & 3,51 & 3,03 \\
Aremonio-Fagion & 3,51 & - \\
Primulo-Fagenion & 1,75 & 1,52 \\
Prunetalia spinosae & 1,75 & 3,03 \\
Indifferens & 10,53 & 28,79 \\
\hline
\end{tabular}

4. táblázat: A fajok flóraelem-csoportok (FLE) szerinti százalékos megoszlásának változása (Id. 3. ábra)

\begin{tabular}{|lccccc|}
\hline \multicolumn{1}{|c}{ flóraelem } & rövidítés & zárt állomány(\%) & $\begin{array}{c}\text { bontott } \\
\text { állomány(\%) }\end{array}$ & $\begin{array}{c}\text { végvágott } \\
\text { állomány (\%) }\end{array}$ & $\begin{array}{c}\text { fiatal állomány } \\
(\%)\end{array}$ \\
eurázsiai & EUA & 23,64 & 17,14 & 18,18 & 29,63 \\
európai & EUR & 23,64 & 28,57 & 27,27 & 14,81 \\
atlanti-szubmediterrán & AsM & 7,27 & 11,43 & 4,55 & 11,11 \\
keleti-szubmediterrán & SMO & 5,45 & 8,57 & 3,03 & 7,41 \\
szubmediterrán & SME & 5,45 & 5,71 & 6,06 & 7,41 \\
adventív & ADV & - & - & 9,09 & 3,7 \\
középeurópai & $\mathrm{CEU}$ & 14,55 & 11,43 & 7,58 & 7,41 \\
cirkumpoláris & $\mathrm{CIR}$ & 7,27 & 5,71 & 6,06 & 7,41 \\
szarmata & $\mathrm{SAR}$ & 1,82 & 2,86 & 1,52 & 3,7 \\
kozmopolita & $\mathrm{KOZ}$ & 3,64 & 2,86 & 13,64 & 3,7 \\
pannon- balkáni & $\mathrm{PaB}$ & 3,64 & 2,86 & - & 3,7 \\
ponto- mediterrán & $\mathrm{PoM}$ & 3,64 & 2,86 & 3,03 & - \\
\hline
\end{tabular}


5. táblázat: A fajok életforma kategóriák (LIFE) szerinti százalékos megoszlásának változása (Id. 4. ábra)

\begin{tabular}{|c|c|c|c|c|c|}
\hline életforma & rövidítés & $\begin{array}{c}\text { zárt } \\
\text { állomány(\%) }\end{array}$ & $\begin{array}{c}\text { bontott állomány } \\
(\%)\end{array}$ & $\begin{array}{c}\text { végvágott } \\
\text { állomány }(\%)\end{array}$ & $\begin{array}{c}\text { fiatal állomány } \\
(\%)\end{array}$ \\
\hline Phanerophyta & MM; M; M-E & 18,18 & 31,43 & 15,15 & 29,63 \\
\hline Chamaephyta & $\mathrm{Ch}$ & 5,45 & 5,71 & 3,03 & 7,41 \\
\hline Hemikryptophyta & $\mathrm{H}$ & 41,82 & 37,14 & 51,52 & 44,44 \\
\hline Hemitherophyta & TH & 1,82 & 2,86 & 6,06 & - \\
\hline Therophyta & Th & 5,45 & 5,71 & 10,61 & - \\
\hline Geophyta & G & 27,27 & 17,14 & 13,64 & 18,52 \\
\hline
\end{tabular}

6. táblázat. A fajok szociális magatartástípus (SBT) szerinti százalékos megoszlása

\begin{tabular}{|lccc|}
\hline \multicolumn{1}{|c}{ szociális magatartás típus } & rövidítés & csoportrészesedés \% & csoporttömeg \% \\
specialisták & $\mathrm{S}$ & 16,36 & 16,94 \\
kompetítorok & $\mathrm{C}$ & 20,00 & 42,49 \\
generalisták & $\mathrm{G}$ & 47,27 & 38,73 \\
zavarástürők & $\mathrm{DT}$ & 10,91 & 1,58 \\
honos gyomfajok & $\mathrm{W}$ & 5,45 & 0,26 \\
\hline
\end{tabular}

\section{7. táblázat. A fajok szociális magatartástípusok (SBT) szerinti százalékos megoszlásának változása}

(Id. 5. ábra)

\begin{tabular}{|lccccc|}
\hline \multicolumn{1}{|c}{ szociális magatartás típus } & rövidítés & zárt állomány(\%) & $\begin{array}{c}\text { bontott állomány } \\
(\%)\end{array}$ & $\begin{array}{c}\text { végvágott } \\
\text { állomány (\%) }\end{array}$ & $\begin{array}{c}\text { fiatal állomány } \\
(\%)\end{array}$ \\
specialisták & $\mathrm{S}$ & 16,36 & 5,71 & 6,06 & 11,11 \\
kompetítorok & $\mathrm{C}$ & 20,00 & 17,14 & 9,09 & 14,81 \\
generalisták & $\mathrm{G}$ & 47,27 & 57,14 & 34,85 & 51,85 \\
természetes pionírok & $\mathrm{NP}$ & & 2,86 & 1,52 & - \\
zavarástürök & $\mathrm{DT}$ & 10,91 & 14,29 & 25,76 & 14,81 \\
honos gyomfajok & $\mathrm{W}$ & 5,45 & 2,86 & 9,09 & 3,70 \\
meghonosodott & $\mathrm{I}$ & - & - & 3,03 & - \\
behurcolt fajok & $\mathrm{A}$ & - & - & 1,52 & - \\
ruderális kompetítorok & $\mathrm{RC}$ & - & - & 4,55 & - \\
agresszív tájidegen inváziós & $\mathrm{AC}$ & - & - & 4,55 & 3,70 \\
fajok & & & & &
\end{tabular}

